\title{
A case study of zeolitization process: "Tufo Rosso a Scorie Nere" (Vico volcano, Italy): inferences for a general model
}

\author{
Daniela Novembre $^{1}$, Domingo Gimeno ${ }^{2}$, Piergiulio Cappelletti ${ }^{3,4}$, and Sossio Fabio Graziano ${ }^{5}$ \\ ${ }^{1}$ Dipartimento di Ingegneria e Geologia, Università degli Studi “G. d'Annunzio" Chieti, \\ Via dei Vestini 3066100 Chieti scalo (CH), Italy \\ ${ }^{2}$ Dept. Mineralogia, Petrologia i Geologia Aplicada, Facultat de Ciències de la Terra, \\ Universitat de Barcelona, 08028 Barcelona, Spain \\ ${ }^{3}$ Dipartimento di Scienze della Terra, dell'Ambiente e delle Risorse, Università degli Studi \\ di Napoli Federico II, via Cintia 26, 80126 Naples, Italy \\ ${ }^{4}$ Centro Musei delle Scienze Naturali e Fisiche, Università degli Studi di Napoli Federico II, \\ via Mezzocannone 8, 80134 Naples, Italy \\ ${ }^{5}$ Dipartimento di Farmacia, Università degli Studi di Napoli Federico II, \\ via D. Montesano 49, 80131 Naples, Italy
}

Correspondence: Daniela Novembre (daniela.novembre@unich.it)

Received: 19 October 2020 - Revised: 7 April 2021 - Accepted: 22 April 2021 - Published: 2 June 2021

\begin{abstract}
This paper focuses on the authigenic mineralization processes acting on "Tufo Rosso a Scorie Nere" (TRS), i.e. one of the main pyroclastic units of the Vico stratovolcano (Latium, Italy). The pyroclastic deposits appear in general massive and made of "black vitreous vesiculated juvenile scoriae", immersed in an ashy matrix lithified after zeolitization processes. The main minerals are chabazite and phillipsite, and the zeolitic content is locally variable, reaching $68 \%$ wt. Zeolites grow replacing both amorphous fraction and pre-existing phases, occurring inside both matrix and scoriae. Concerning scoriae, zeolitization moves from the rim to the core of the scoriaceous fragment as a function of (a) temperature of the fluids and (b) permeability (primary or secondary). Composition of parental fresh glass and that of zeolitized rocks is compatible with trachyte chemistry, lightly undersaturated in $\mathrm{SiO}_{2}$, and the alteration processes modified the parental rock chemical features. Zeolites genesis is ascribed to a "geoautoclave-like system", and zeolites display a $\mathrm{Si} / \mathrm{Al}$ ratio similar to that of the parental glasses. TRS presents promising mineralogical characteristics as supplementary cementitious material in the production of mixed cements.
\end{abstract}

\section{Introduction}

Zeolites are used in technological applications as both synthetic or natural products. Natural deposits are mainly related to glassy volcanoclastic rocks and saline-lake sedimentary genetic environments (Langella et al., 2013). A large number of currently exploited deposits are related to a particular type of large-sized pyroclastic deposits (ignimbrites) with high alkali and high silica natural content (alkali rhyolites, trachytes, phonolites, etc.) and radially disposed around stratovolcanoes.

A large number of these deposits show a high zeolitic content (ranging from $50 \%$ to $95 \%$ ) and sometimes a near- monomineralic or bimineralic feature that can be useful for a large range of industrial applications, with an economical advantage in comparison with synthetic counterparts but also with other minerals such as clays (i.e. common zeolitic rocks usually have cation exchange capacity (CEC) that is twice or more than the more efficient clays).

Zeolitites (rocks with more than $50 \%$ in zeolite content) have been used since ancient times (in construction, as lightweight dimension stone and for the production of pozzolanic cements and concrete); other uses are in the field of soil amendment and water regulation output in agriculture, while most of them have been extensively developed in 
the last half century: hydroponic agronomy and horticulture; water and wastewater treatment, soil decontamination from heavy metals and radioactive elements, adsorption and catalysis, aquaculture and animal feeding, pet litter and animalwaste treatment, purification and separation of gases, etc. (Ackley et al., 2003; Wang and Peng, 2010; R. de Gennaro et al., 2009, and references therein; B. de Gennaro et al., 2009).

Natural zeolites are used for various other technical applications rather than their main use as cation exchangers.

Thanks to their pozzolanic activity, zeolites can also be used as supplementary cementitious material (SCM) in the production of mixed cements (Snellings et al., 2012). The use of these new SCM represents a very important aspect that allows the reduction of the quantities of Portland cement used, effectively reducing, on the other hand, environmental impact of its production and allowing a significant reduction of the $\mathrm{CO}_{2}$ released during the production of cement, which is the third largest source of anthropogenic $\mathrm{CO}_{2}$ emissions (Andrew, 2018).

Recent studies demonstrated that the pozzolanic activity of a rock, used as SCM, depends on numerous factors, including specific assembly of mineralogical phases of the rock, grain size of the reactive phases, and their behaviour during industrial processing, i.e. grinding and heat treatment. Combination of these factors complicates the prediction of reactivity (Mertens et al., 2009; Snellings et al., 2010a, b; Özen et al., 2016), recalling in any case the need to specifically evaluate the use of deposits which are promising for their mineralogical features.

Thus, the economic interest of these deposits justifies a complete study of their main features and genesis, mainly related to alteration of the pyroclastic rocks.

As far as zeolitic formation is concerned, a large number of authors described alteration processes acting on pyroclastic deposits, observing how these processes led to the lithification by replacement of the glassy fraction by authigenic zeolites (Cappelletti et al., 2015; Langella et al., 2013). Temperature and chemical composition of the glass play an important role in determining the type of authigenic minerals formed. According to de Gennaro et al. (1987), phillipsite and chabazite form from trachytic glass, phonolite glasses lead to the formation of mainly chabazite, and alkali-trachytic glasses lead to chabazite either alone or associated with phillipsite. The eventuality of a peculiar alteration type occurring and its variable areal occurrence in a volcanic deposit strongly reflect fluctuating emplacement conditions, especially in terms of cooling rates and, concerning zeolites, water content. In order to test (a) the role of temperature in the crystallization of different zeolitic phases and (b) to highlight the natural zeolite occurrences, de Gennaro and Colella (1991) treated trachytic and phonolitic glasses with deionized water at temperatures ranging from 100 to $270^{\circ} \mathrm{C}$, showing that zeolitization began with formation of phillipsite at temperatures between 100 and $250^{\circ} \mathrm{C}$, consecutively analcime and K-feldspars. The presence of chabazite, on the contrary, is revealed for long times and at temperatures ranging from 150 to $270^{\circ} \mathrm{C}$.

In the last 40 years research on Italian quaternary pyroclastic deposits as sources of zeolitic minerals has greatly developed. Most studies focused on the possible mechanisms of zeolite formation, and several genetic hypotheses were proposed (Langella et al., 2013; Cappelletti et al., 2015; Colella et al., 2017). The purpose of this work is the study of zeolitization processes occurring at Vico volcano, with particular attention to the identification of the type of zeolites, genetic mechanisms, and factors that influenced/conveyed the volcanic alteration process.

Vico is a stratovolcano located in northern Latium (Italy) and is part of the potassium-rich Roman Volcanic province (Peccerillo et al., 1987; Beccaluva et al., 1991; Conticelli and Peccerillo, 1992; Serri et al., 1993). Vico volcanic products display an ultrapotassic character, in a range of rock composition extremely variable from leucite-bearing tephrites, trachybasalts, tephri-phonolites, to trachytes (Novembre et al., 2004; Aulinas et al., 2011).

The TRS (red tuff with black juvenile scoriaceous clasts and bombs) belongs to the Ignimbrite $\mathrm{C}$ formation, i.e. the largest pyroclastic flow of the Vico plateau and one of the most widespread pyroclastic deposits of Lazio region, extending on a surface of about $1300 \mathrm{~km}^{2}$, also known as "Sutri Formation" of the "Lago di Vico Synthem" (Perini et al., 1997). The average thickness of the formation is about $40 \mathrm{~m}$, and the TRS zeolitization refers to the presence of chabazite and subordinately phillipsite and analcime, as reported by de Gennaro and Langella (1996). TRS is commercialized as dimension stone, in animal feeding (de Gennaro and Langella, 1996) and pet litter, and its suitability as raw material for the synthesis of zeolites for chemical industry has been proven (Novembre et al., 2004). Additional experiments on its behaviour as an excellent uptake agent from water have been developed (Ruggieri et al., 2008).

Rock samples have been collected from quarries located in the southeastern sector of Vico lake (Fig. 1): Civita Castellana (three samples from Tufitalia quarry: TQ1-TQ2-TQ3), Sutri (two samples from Monte del Tempio quarry: MTQ1MTQ2), and Castel Sant'Elia (two samples from La Bannita quarry: BANQ1-BANQ2). All these quarries are located in the ignimbrite $\mathrm{C}$ formation, as desumed by the very high degree of compositional homogeneity and an almost total lack of zoning in the vertical sense, as reported by Giampaolo et al. (2008). TRS pyroclastic flow deposits appear in general essentially massive and commonly made of "black vitreous vesiculated juvenile scoria" (hereafter BVVJS), usually immersed in a grey to yellow ash matrix lithified after zeolitization processes. 


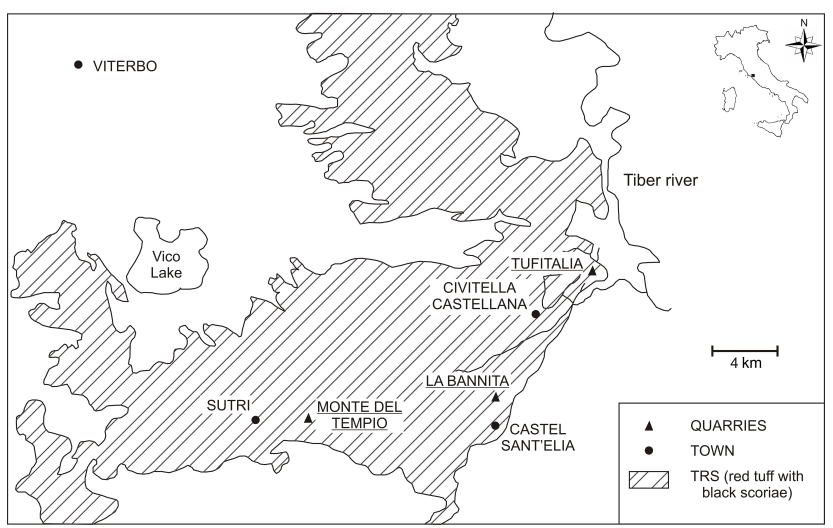

Figure 1. Location map of the different pits (Monte Tempio Tufitalia and La Bannita) relative to the Ignimbrite $\mathrm{C}$ vicanian formation.

\section{Analytical techniques}

Bulk rock mineralogy was investigated by X-ray powder diffraction (XRPD) at the Dipartimento di Ingegneria e Geologia dell' Università di Chieti (Italy), with a Siemens D5000 diffractometer operating with a Bragg-Brentano geometry, equipped with $\mathrm{CuK} \alpha$ radiation, $40 \mathrm{kV}, 40 \mathrm{~mA}, 2-90^{\circ}$ 2theta scanning interval, step size $0.02^{\circ} 2$ theta, a divergence slit of $0.5^{\circ}$, and a receiving slit of $0.1 \mathrm{~mm}$. Identification of zeolites was performed with reference to the following JCPDS codes: 00-046-1427 for phillipsite, 00-034-0137 for chabazite, and 00-041-1478 for analcime. Both crystalline and amorphous contents were estimated using quantitative phase analysis (QPA) applying the combined Rietveld and reference intensity ratio (RIR) methods; corundum NIST 676a was added to each sample, amounting to $10 \%$, according to the strategy proposed by Novembre et al. (2018), and the powder mixtures were homogenized by hand-grinding in an agate mortar. Data for the QPA refinement were collected in the angular range $5-120^{\circ}$ 2theta with steps of $0.02^{\circ}$ and 10 second per step (see Novembre et al., 2018, 2019). Data were processed with GSAS software (Larson and Von Dreele, 1997) and its graphical interface EXPGUI (Toby, 2001). The unit cell parameters were determined starting with the structural models proposed by Gatta et al. (2009) for phillipsite and Gualtieri and Passaglia (2006) for chabazite. The following parameters were refined: wt $\%$, background parameters, zero shift, cell parameters, and peak profiles (Novembre and Gimeno, 2017). To obtain the percentages of the mineralogical phases, the output data of the refinements were multiplied by the factor $K$ (Gualtieri, 2000). The percentage of the glass was obtained by difference of 100 with respect to the other phases.

Chemical compositions of the bulk TRS zeolitized rocks and of separated BVVJS were determined by X-ray fluorescence (XRF), with a sequential X-ray spectrophotometer PHILIPS PW 2400, at the Serveis Cientifico-Tècnics of the Universitat de Barcelona (SCT-UB), Spain. Major element determination has been carried out using fused pearls (lithium tetra borate pearls at a dilution of $1 / 20$ ). Pearls were obtained by triplicate in a Pt crucible and collector dishes, using LiI as a viscosity corrector. Trace elements were determined by duplicate on powder-pressed pellets $(6 \mathrm{~g}$ of sample treated with elvacite resin in an $\mathrm{Al}$ recipient on a basis of boric acid). The spectrometer was calibrated using a set of more than 60 international standards. A separate set of international standards provided by GSJ (Geological Survey of Japan) was used as inner control of the quality of results. $\mathrm{Na}_{2} \mathrm{O}$ was determined by atomic absorption spectroscopy (AAS), with previous total solubilization of the sample. All samples were carefully treated at $130^{\circ} \mathrm{C}$ in pyrex recipients for $48 \mathrm{~h}$ prior to any other manipulation. Loss on ignition (LOI) of $1 \mathrm{~g}$ of sample was obtained in a ceramic crucible running on an oxidizing furnace.

A CAMECA Camebax SX-50 EMPA-WDS, installed at SCT-UB, was used for electron microprobe analyses (EMPA) of zeolitic and non-zeolitic minerals. Different natural and synthetic silicates and oxides of certified composition were used as standards (P\&H Developments and Agar Scientific commercial standard blocks). The analysing crystals were provided by CAMECA (LIF, TAP, and PET). Chemical data of single crystals or clusters of chabazite, phillipsite, and analcime of enriched samples obtained with the method described by Cappelletti et al. (2015) were integrated with $\mathrm{H}_{2} \mathrm{O}$ content determined by thermal analyses on single zeolites (thermogravimetry, TG) using a Netzch STA 409 multiple thermoanalyser at the following operating conditions: $0.09 \mathrm{~g}$ of material in a $\mathrm{Al}_{2} \mathrm{O}_{3}$ crucible sample holder, heating rate $10^{\circ} \mathrm{C} \mathrm{min}^{-1}$, and final temperature $1000^{\circ} \mathrm{C}$ (Novembre et al., 2019).

Mineral characterizations (microtextural analysis, SEM) were carried out with a JEOL J3M-840 SEM, equipped with a LINK EDS spectrometer, operating at $15 \mathrm{kV}, 10 \mathrm{~mA}$. Zeolitic samples were carefully treated before any observation, drying them at $80^{\circ} \mathrm{C}$ overnight; then they were mounted on a $\mathrm{Al}$ stub and double metal coated (graphite and vaporized $\mathrm{Au}$, successively) (Novembre and Gimeno, 2014).

Thermodynamic modelling was evaluated using the Geochemist's Workbench software package (GWB, Standard release 9.0). The ACT2 module of GWB was used for activityactivity diagrams. The internal database was implemented with chemical analyses of investigated zeolites; $\mathrm{H}_{2} \mathrm{O}$ and silica activity values were chosen to be consistent with the investigated system (Stumm and Morgan, 1981; Wolery et al., 1984; Langella et al., 2013). 


\section{Results}

\subsection{Mineralogy and petrography of TRS}

TRS pyroclastic flow deposits appear mainly massive and constituted of black vitreous vesiculated juvenile scoria (BVVJS), immersed in a grey to yellow ashy matrix, lithified after zeolitization processes. BVVJS are vitreous and black in colour, with a porphyritic texture containing leucite and sanidine; they commonly show a characteristic reddish colour when completely zeolitized (Novembre et al., 2004).

Bulk compositions of zeolitized TRS rock samples are reported in Table 1, while the compositions of their BVVJS fractions are reported in Table 2.

XRPD analyses reveal that TRS rocks are mainly constituted of chabazite, phillipsite, and minor amounts of sanidine, leucite and/or analcime, pyroxene, and plagioclase (Table 3). The Supplement reports the chemical composition of sanidines (Table S1), leucites (Table S2), pyroxenes (Table S3), plagioclases (Table S4), and analcimes (Table S5).

Clinopyroxene is present as phenocrystals or microlites inside the groundmass of rock samples. Their compositions lay in the field of the diopside-salite, with an $\mathrm{X}_{\mathrm{Mg}}$ ranging between 0.81 and 0.87 . Sanidine compositions range from $\mathrm{Or}_{77.45}$ to $\mathrm{Or}_{86.73}$; some crystals show high $\mathrm{BaO}$ contents of about $1.43 \mathrm{wt} \%$ (Table S3).

Plagioclase compositions are variable from labradoritic up to bytownitic with direct and rhythmic zonings; these crystals are also rich in glassy inclusions (Table S4).

Leucite is present as phenocrystals inside fresh BVVJS. Leucites often include pyroxene crystals (Table S2).

Mineralogical formulae of analcimes are calculated on the basis of $96 \mathrm{O}$ (Table S5); the presence of $\mathrm{K}$ in the chemical analyses, also noticed in analcime crystals of the "Tufo Giallo della Via Tiberina" rocks (Cappelletti et al., 2015), led us to hypothesize a genetic mechanism related to the transformation of leucite crystals by interaction with Na-rich solutions (Giampaolo and Lombardi, 1994). Fresh glass probably represented the source for $\mathrm{Na}$ of analcime, and dissolution of $\mathrm{Na}$ into calcium-bicarbonate-rich fluids vehicled the analcimization process itself.

In Fig. 2 variations in main mineralogical phases (zeolites and others) for the three quarries are reported. TRS zeolitic content here ranges from $57 \mathrm{wt} \%$ (MTQ2 sample, Monte del Tempio Quarry, Sutri) and up to $68 \mathrm{wt} \%$ of the rock (BQ12 sample, Bannita Quarry, Castel S. Elia); however, zeolitic average content is about $61 \mathrm{wt} \%$.

BVVJS were classified following the standard procedure of IUGS (Le Maitre, 1989) (Fig. 3). BVVJS fractions of TRS lay across the line dividing the phonolitic from the trachytic field; data on host rocks (Sutri Formation from Perini et al., 1997) are also reported in the figure, laying in the field of phonolites.

Crystallization of the parental melts was followed in the tetrahedron $\mathrm{SiO}_{2}-\mathrm{NaAlSiO}_{4}-\mathrm{KAlSiO}_{4}-\mathrm{CaAl}_{2} \mathrm{Si}_{2} \mathrm{O}_{8}$. The

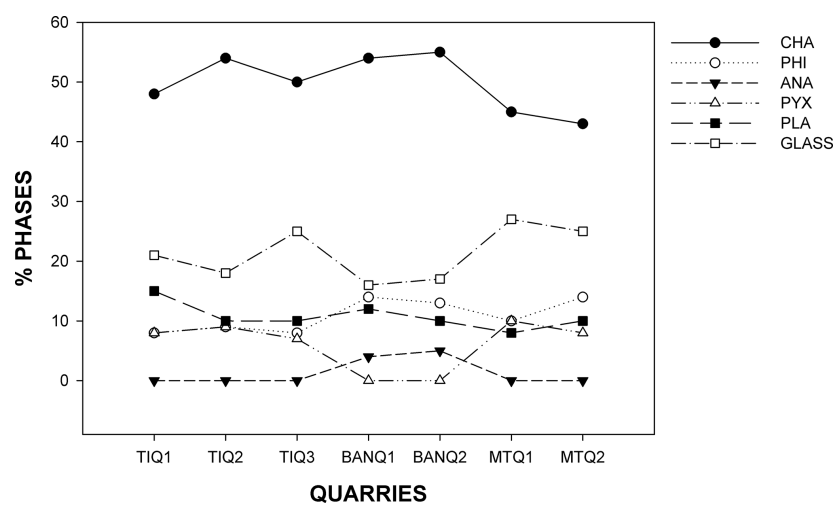

Figure 2. Weight percent variation in main mineralogical phases (calculated with the QPA Rietveld and RIR method) for the three quarries. CHA: chabazite; PHI: phillipsite; ANA: analcime; PYX: pyroxene; PLA: plagioclase.

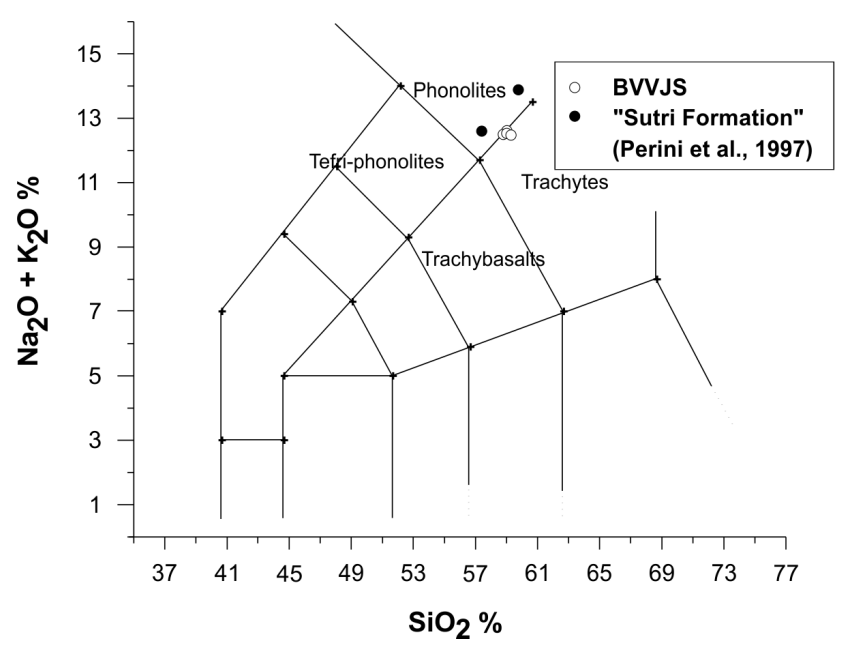

Figure 3. Total alkali silica diagram after Le Maître (1989).

plane $\mathrm{NaAlSi}_{3} \mathrm{O}_{8}-\mathrm{KAlSi}_{3} \mathrm{O}_{8}-\mathrm{CaAl}_{2} \mathrm{Si}_{2} \mathrm{O}_{8}$ has been projected on the base of this tetrahedron (phonolitic pentahedron sensu Baldridge et al., 1981) (Fig. 4). Compositions of TRS zeolitized rocks, BVVJS, and leucites, without anorthite, are plotted in the undersaturated part of the phonolitic pentahedron. Compositions of plagioclases (Table S4), sanidines (Table S1), and total feldspars (plagioclases + sanidines) are shown on the ternary feldspar part of the phonolitic pentahedron. As is visible, compositions of BVVJS and those of TRS zeolitized rock lay just below the Ab-Or line and can be defined as trachyte slightly undersaturated in $\mathrm{SiO}_{2}$.

\subsection{Zeolitization on TRS and zeolitic chemistry}

Mineralogical investigations and chemical analyses show that zeolitization processes greatly affect TRS, both rock matrix and scoria fragments. The main zeolitic phase occurring in the TRS is chabazite and secondarily phillipsite, the former mainly distributed inside the rock matrix, the latter 
Table 1. Bulk chemical composition of TRS rock samples (wt \% for major elements and parts per million for minor elements). MTQ1-2: Monte del Tempio quarry, location Sutri; TIQ1-3: Tufitalia quarry, location Civita Castellana; BANQ1-2: La Bannita quarry, location Castel S. Elia. LOI: loss on ignition. bdl: Below detection limit. CIPW values are reported for graphical representation. Mineral abbreviations as reported in Whitney and Evans (2010).

\begin{tabular}{|c|c|c|c|c|c|c|c|}
\hline & MTQ1 & MTQ2 & TIQ1 & TIQ2 & TIQ3 & BANQ1 & BANQ2 \\
\hline $\mathrm{SiO}_{2}$ & 51.82 & 51.68 & 54.38 & 52.46 & 53.75 & 49.65 & 51.21 \\
\hline $\mathrm{TiO}_{2}$ & 0.77 & 0.46 & 0.57 & 0.52 & 0.51 & 0.52 & 0.50 \\
\hline $\mathrm{Al}_{2} \mathrm{O}_{3}$ & 16.82 & 18.16 & 17.81 & 17.46 & 16.86 & 16.48 & 17.55 \\
\hline $\mathrm{Fe}_{2} \mathrm{O}_{3}$ & 5.46 & 3.56 & 4.48 & 3.69 & 4.00 & 4.38 & 3.54 \\
\hline $\mathrm{MnO}$ & 0.13 & 0.11 & 0.13 & 0.12 & 0.10 & 0.11 & 0.12 \\
\hline $\mathrm{MgO}$ & 1.42 & 1.18 & 1.33 & 1.06 & 1.55 & 1.57 & 0.76 \\
\hline $\mathrm{CaO}$ & 4.05 & 4.01 & 4.87 & 5.10 & 5.21 & 5.50 & 3.88 \\
\hline $\mathrm{Na}_{2} \mathrm{O}$ & 2.10 & 1.85 & 3.93 & 2.90 & 1.60 & 1.80 & 2.80 \\
\hline $\mathrm{K}_{2} \mathrm{O}$ & 8.31 & 5.74 & 6.37 & 8.40 & 8.15 & 7.70 & 7.09 \\
\hline $\mathrm{P}_{2} \mathrm{O}_{5}$ & 0.24 & 0.17 & 0.32 & 0.23 & 0.27 & 0.25 & 0.26 \\
\hline LOI & 7.77 & 12.55 & 3.88 & 7.02 & 7.37 & 11.13 & 11.45 \\
\hline Tot. & 98.89 & 99.47 & 98.07 & 98.96 & 99.37 & 99.10 & 99.16 \\
\hline V & 118 & 84 & 123 & 95 & 78 & 98 & 85 \\
\hline Co & 23 & 8 & 49 & 40 & 25 & 27 & 40 \\
\hline $\mathrm{Ni}$ & 9 & 6 & bdl & bdl & bdl & 9 & bdl \\
\hline $\mathrm{Cu}$ & 22 & 11 & 10 & 7 & 6 & 12 & 4 \\
\hline $\mathrm{Zn}$ & 108 & 67 & 79 & 75 & 64 & 73 & 72 \\
\hline $\mathrm{Rb}$ & 386 & 455 & 404 & 361 & 409 & 399 & 648 \\
\hline $\mathrm{Sr}$ & 1080 & 1212 & bdl & 1274 & 1301 & 1213 & 662 \\
\hline $\mathrm{Ba}$ & 807 & 918 & 884 & 777 & 786 & 628 & 833 \\
\hline $\mathrm{Pb}$ & 135 & 73 & 63 & 84 & 78 & 87 & 79 \\
\hline $\mathrm{Y}$ & 48 & 37 & 42 & 39 & 32 & 37 & 50 \\
\hline $\mathrm{Zr}$ & 685 & 433 & 576 & 572 & 373 & 452 & 560 \\
\hline $\mathrm{Nb}$ & 42 & 25 & 27 & 27 & 19 & 24 & 31 \\
\hline Th & 119 & 63 & 85 & 87 & 43 & 65 & 95 \\
\hline $\mathrm{Sn}$ & 11 & 5 & bdl & 3 & 2 & 5 & 5 \\
\hline $\mathrm{Ga}$ & 17 & 16 & 18 & 16 & 17 & 15 & 14 \\
\hline W & 62 & Bdl & 266 & 184 & 143 & 120 & 97 \\
\hline $\mathrm{Ce}$ & 269 & 221 & 270 & 254 & 190 & 223 & 281 \\
\hline $\mathrm{Qz}$ & - & 9.06 & - & - & 1.3 & - & - \\
\hline Crn & - & 2.33 & - & - & - & - & - \\
\hline Or & 54.13 & 39.14 & 40.10 & 54.11 & 52.52 & 51.92 & 47.91 \\
\hline $\mathrm{Ab}$ & 16.09 & 18.06 & 28.23 & 12.94 & 14.76 & 12.27 & 25.55 \\
\hline An & 13.14 & 21.67 & 12.91 & 10.7 & 16.08 & 16.14 & 16.44 \\
\hline $\mathrm{Nph}$ & 1.89 & - & 3.92 & 7.47 & - & 2.77 & 0.83 \\
\hline $\mathrm{Di}$ & 6.04 & - & 8.77 & 8.03 & 8.35 & 10.77 & 3.03 \\
\hline Нyp & - & 6.49 & - & - & 3.36 & - & - \\
\hline $\mathrm{Ol}$ & 3.86 & - & 2.04 & - & - & 2.16 & 2.70 \\
\hline Mag & 2.62 & 1.79 & 2.08 & 2.91 & 1.90 & 2.17 & 1.76 \\
\hline $\mathrm{Ilm}$ & 1.61 & 1.01 & 1.15 & 1.08 & 1.06 & 1.13 & 1.09 \\
\hline Ap & 0.63 & 0.46 & 0.81 & 0.61 & 0.7 & 0.69 & 0.70 \\
\hline Wo & - & - & - & 2.17 & - & - & - \\
\hline $\mathrm{K}_{2} \mathrm{O} / \mathrm{Na}_{2} \mathrm{O}$ & 3.96 & 3.10 & 1.62 & 2.90 & 5.09 & 4.28 & 2.53 \\
\hline
\end{tabular}

more concentrated inside scoriae, as previously reported by de Gennaro and Langella (1996), Giampaolo et al. (2008), and Ciccioli et al. (2010).

Figure $5 \mathrm{a}-\mathrm{b}$ represent a reconstruction of mineralogical changes occurring inside a single scoriaceous element. A section performed on single scoria from outer to inner regions (see A-B in Fig. 5a) indicates the presence of concentric mineralogical zonings. These findings were verified for all investigated zeolitized rock samples and relative to the different quarries in Fig. 1. In particular, from external 
Table 2. Chemical analyses of BVVJS (wt \% for major elements); 1-2: Tufitalia quarry, location Civita Castellana; 3: La Bannita quarry, location Castel S. Elia; 4-5: Monte del Tempio quarry, location Sutri. CIPW values are reported for graphical representation. Mineral abbreviations as reported in Whitney and Evans (2010).

\begin{tabular}{lrrrrr}
\hline & BVVJS-1 & BVVJS-2 & BVVJS-3 & BVVJS-4 & BVVJS-5 \\
\hline $\mathrm{SiO}_{2}$ & 56.61 & 56.64 & 56.59 & 56.58 & 56.63 \\
$\mathrm{TiO}_{2}$ & 0.55 & 0.53 & 0.50 & 0.55 & 0.49 \\
$\mathrm{Al}_{2} \mathrm{O}_{3}$ & 18.65 & 18.45 & 18.39 & 18.51 & 18.63 \\
$\mathrm{Fe}_{2} \mathrm{O}_{3}$ & 3.80 & 3.71 & 3.74 & 3.90 & 3.75 \\
$\mathrm{MnO}$ & 0.14 & 0.11 & 0.13 & 0.13 & 0.10 \\
$\mathrm{MgO}$ & 0.81 & 0.80 & 0.83 & 0.82 & 0.85 \\
$\mathrm{CaO}$ & 3.45 & 3.35 & 3.65 & 3.60 & 3.46 \\
$\mathrm{Na} 2 \mathrm{O}$ & 3.38 & 3.41 & 3.27 & 3.39 & 3.30 \\
$\mathrm{~K}_{2} \mathrm{O}$ & 8.62 & 8.50 & 8.79 & 8.63 & 8.70 \\
$\mathrm{H} 2 \mathrm{O}$ & 2.70 & 2.65 & 2.73 & 2.69 & 2.75 \\
\hline $\mathrm{TOT}$ & 98,71 & 98.15 & 98.62 & 98.80 & 98.66 \\
\hline $\mathrm{Or}$ & 53.21 & 50.82 & 54.33 & 53.22 & 53.76 \\
$\mathrm{Ab}$ & 20.89 & 21.82 & 19.27 & 20.17 & 20.49 \\
$\mathrm{An}$ & 10.72 & 10.05 & 9.98 & 10.23 & 10.8 \\
$\mathrm{Nph}$ & 4.86 & 3.99 & 5.23 & 5.28 & 4.71 \\
$\mathrm{Di}$ & 5.99 & 5.63 & 7.49 & 7.04 & 5.97 \\
$\mathrm{Ol}$ & 1.5 & 1.22 & 1.01 & 1.19 & 1.59 \\
$\mathrm{Mag}$ & 1.73 & 5.44 & 1.7 & 1.77 & 1.71 \\
$\mathrm{Ilm}$ & 1.1 & 1.02 & 0.99 & 1.09 & 0.97 \\
\hline $\mathrm{K} 2 \mathrm{O} / \mathrm{Na}_{2} \mathrm{O}$ & 2.55 & 2.49 & 2.69 & 2.55 & 2.64 \\
\hline
\end{tabular}

Table 3. Mineralogical composition of the studied samples. Zeol: zeolites (chabazite and phillipsite); px: pyroxene; fel: sanidine and plagioclase; lct: leucite; ana: analcime.

\begin{tabular}{llrrrrrrr}
\hline Sample & Quarry & $\%$ cha & $\%$ phi & $\%$ ana/lct & $\%$ zeol & $\%$ px & $\%$ fel & $\%$ glass \\
\hline TIQ1 & Tufitalia & $48 \pm 5$ & $8 \pm 1$ & 0 & $56 \pm 9$ & $8 \pm 1$ & $15 \pm 1$ & $17 \pm 2$ \\
TIQ2 & Tufitalia & $54 \pm 6$ & $9 \pm 1$ & 0 & $63 \pm 8$ & $9 \pm 1$ & $10 \pm 1$ & $18 \pm 2$ \\
TIQ3 & Tufitalia & $50 \pm 4$ & $8 \pm 1$ & 0 & $58 \pm 9$ & $7 \pm 1$ & $10 \pm 1$ & $25 \pm 3$ \\
BANQ1 & La Bannita & $54 \pm 6$ & $14 \pm 2$ & $4 \pm 1$ & $72 \pm 7$ & 0 & $12 \pm 1$ & $16 \pm 2$ \\
BANQ2 & La Bannita & $55 \pm 7$ & $13 \pm 1$ & $5 \pm 1$ & $73 \pm 7$ & 0 & $10 \pm 1$ & $17 \pm 2$ \\
MTQ1 & Mt Tempio & $45 \pm 5$ & $10 \pm 1$ & 0 & $55 \pm 8$ & $10 \pm 1$ & $8 \pm 1$ & $27 \pm 3$ \\
MTQ2 & Mt Tempio & $43 \pm 4$ & $14 \pm 2$ & 0 & $57 \pm 7$ & $8 \pm 1$ & $10 \pm 1$ & $25 \pm 2$ \\
\hline
\end{tabular}

to internal area of single scoriae, transitions from chabazite, chabazite-phillipsite to black glass containing sanidine and leucite crystals (the latter very often alterating in analcime) were observed (Fig. 5).

Chabazite appears as pseudocubic crystals (of about $60 \mu \mathrm{m}$ ) and frequently in aggregates in TRS matrix (area 1 in Fig. 5b) and in the more external scoriaceous regions (area 2 in Figs. 5b and 6a); it is possible to observe phillipsite crystals embedded in chabazite (area 2 in and Figs. 5 and $6 \mathrm{~b}$ ), suggesting that chabazite represents a late-formed phase; phillipsite appears as acicular clusters (diameter of about $170 \mu \mathrm{m}$ ) constituted by thin prismatic crystals growing inside scoriae (area 2 in Figs. 5 and 6c, d and e); proceeding inside scoriae, isolated analcime crystals can be found replacing glass (area 3 in Figs. 5 and 6f).
Tables 4 and 5 show chemical compositions of zeolites. In particular, Table 4 reports data for chabazite of areas 1 and 2 in Fig. 5 b; Table 5 shows data for phillipsite of area 2 in Fig. 5b. Compositions of sanidine and leucite crystals (Tables S1-S2), just discussed in the above paragraph, refer to area 3 in Fig. 5b. Compositions of analcime reported in Table S5 refer to area 3 in Fig. 5 b.

Compositions of glasses (BVVJS), phillipsite, and chabazite are plotted in the triangular diagrams of exchangeable cation contents (Fig. 7a). The clear affinity of phillipsite to potassium and of chabazite to calcium can be observed.

The diagrams of Fig. $7 \mathrm{~b}$ and $\mathrm{c}$ report the cationic composition of chabazites and phillipsite analysed in this work and of zeolites from literature relative to "open" and "closed" hydrologic systems (Sheppard and Gude, 1970, 1973; Hay, 




Figure 4. Projections of plagioclases, feldspars, total feldspars, leucites (symbols in figure) and of zeolitized rocks (full triangles) and BVVJS (empty squares) on the base of the phonolite pentahedron with ternary feldspar plane rotated into the plane $\mathrm{NaAlSiO}_{4}-\mathrm{KalSiO}_{4}-\mathrm{SiO}_{2}$. The boundary lines for $\mathrm{Ph}_{2} \mathrm{O}$ of $1 \mathrm{~atm}$ is from Baldridge et al. (1981); those at 1 and 2 Kbars are taken from Gittings (1979). The triangle ABC encloses compositions of TRS zeolitized rocks and of BVVJS.

1964; Iijima and Harada, 1969), together with compositions of Bagnoregio chabazites and phillipsites (Vulsini District; Passaglia et al., 1990) and Ignimbrite C chabazites (Cappelletti et al., 1999). As is visible, phillipsite compositions fall in a limited area, while chabazites are scattered over a larger area. As is shown, both phillipsites and chabazites are characterized by strong analogies with the Bagnoregio zeolites; moreover, both chabazites and phillipsite are characterized by higher $\mathrm{K}$ content compared to sedimentary zeolites of closed hydrologic systems and open hydrologic systems from literature, and this agrees with the potassic affinity of these volcanic products.

A comparison between the compositions of parent glasses and those of associated zeolites, expressed as quantitative variations in the elements $\mathrm{Si}, \mathrm{Al} \mathrm{Na}, \mathrm{Ca}$, and $\mathrm{K}$ during the zeolitization process, is illustrated in Fig. 8. Data of Tables 2, 4, and 5 have been recalculated on the basis of 80 oxygens, i.e. half of the Barth's anhydrous standard cell content (Barth, 1952) (see Table S6). Si and Al substantially does not change from glass to zeolites. Concerning cations, $\mathrm{Na}$ diminishes during zeolitization. Calcium generally increases in chabazites and increases more slightly in phillipsites, lightly decreasing only in phillipsites of Tufitalia Quarry. Concerning potassium, it generally increases in phillipsites and decreases in chabazites.

\section{Discussion}

As explained above and illustrated in Fig. 5, mineralogical changes occur inside scoriae. SEM observations and chemical data indicate the presence of an external area zeolitized with chabazite, gradually followed by a successive one zeolitized mainly with phillipsite; then analcime follows, and finally fresh glass with leucite and sanidine can be found.

Occurrence of remnant fresh glass in the central part of scoriae is not a constant feature. In both macroscopic observation and SEM analysis, in fact, a complete spectrum of alteration of the juvenile scoriaceous fractions, which ranges between totally fresh vesiculated scoria and completely zeolitized mass, passing through out all the intermediate possibilities, is revealed.

In particular, secondary processes acting on scoriae move from the rim to the core of scoria themselves as a function of rock porosity induced by cracks and/or grain interfaces promoting fluid circulation. Distribution of water, gas, and heat, in general, is not uniform inside TRS deposit, thus generating complex and variable microsystems (Langella et al., 2013; Cappelletti et al., 2015; Colella et al., 2017).

At the scale of TRS scoriaceous elements, for example, moving from outer to inner regions, it results in a passage through mineralogical phases characterized by a decreas- 


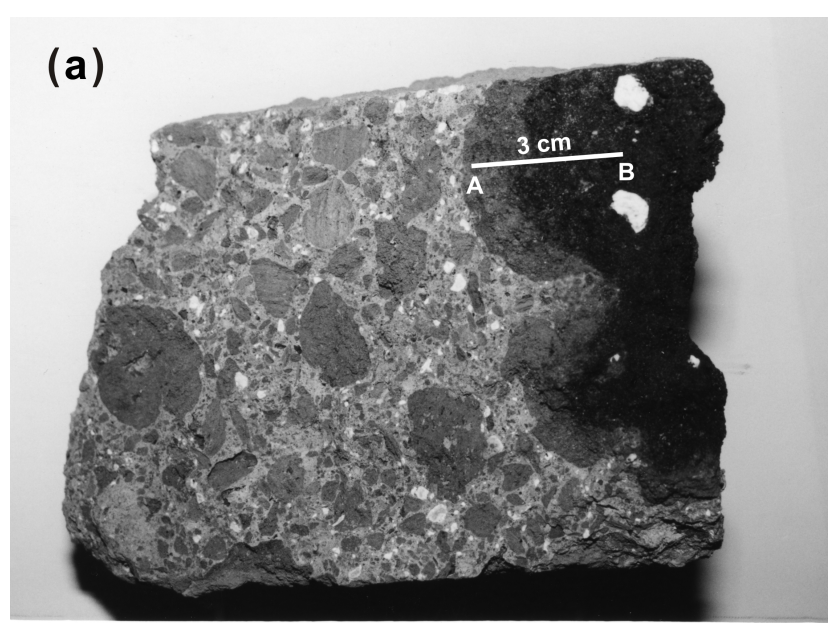

(b)

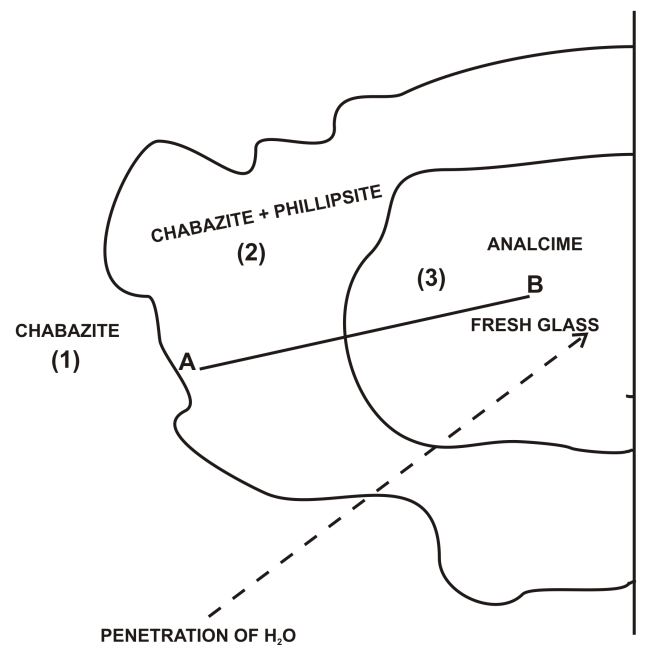

Figure 5. (a) TRS sample at macroscopic scale; A-B: section from the outer rim to the internal core of a scoriaceous element. (b) Scheme of mineralogical changes occurring inside a single scoriaceous element (modified after Novembre, 2003).

ing structural water content; EMPA and TG analyses, in fact, show that hydration of phases decreases passing from chabazite to phillipsite, analcime, and finally fresh glass (Tables S4 and S5).

As evidenced above, chabazite preferably crystallizes inside the TRS ashy matrix, while phillipsite is favoured inside scoriae fragments. This evidence is probably the expression of starting differences in permeability between pumices and matrix. The variable permeability of the different pyroclastic elements (i.e. scoriae and matrix) strongly controls fluid-glass interactions; the ashy matrix will certainly display a higher permeability with respect to scoriae. So, phillipsite, which is a zeolite characterized by lower water content than chabazite, will concentrate inside scoriae; vice versa, chabazite, being more water rich, will concentrate inside matrix. Esposito et al. (2013) investigated the mechanical properties of a number of pyroclastic soils derived from volcanic eruptions (pozzolana and pumice) in the Campanian
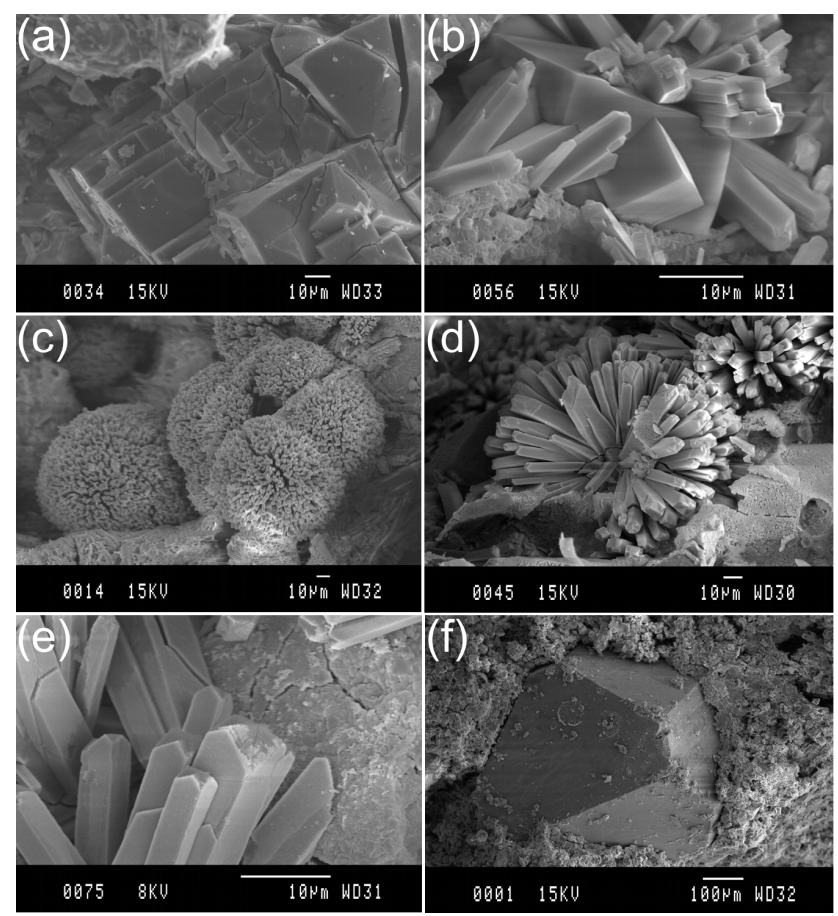

Figure 6. SEM images of phillipsite and chabazite crystals. (a) Chabazite crystals; (b) phillipsite crystals embedded in chabazite; (c), (d), and (e) phillipsite crystals; (f) analcime crystal inside fresh glass (modified after Novembre, 2003; Novembre et al., 2004).

region of central Italy. Although the analysed samples come from the Phlegraean and Vesuvian areas, the conclusions and observations on their mechanical properties can be considered similar for most volcanic soils. The authors found from the experimental results that the characteristic of the material to swell is indirectly dependent on the content of pumice; i.e. pozzolana swells in the absence of the pumice, thus confirming the more impermeable character of pumice fragments.

The occurrence of a given zeolite assemblage in a specific volcanic deposit strongly depends on water availability. It is a fact that chabazite, containing a greater quantity of structural water, is concentrated in the more permeable matrix, while phillipsite with less structural water is concentrated in the less permeable pumice.

When comparing chemical analyses of bulk rocks (Table 1) with those of BVVJS (Table 2), in the scoriae fragments the system is strongly more sodic with respect to the potassic nature of the whole rock, because the crystallization of phillipsite mainly occurs in scoriae while that of chabazite mainly in the matrix.

Moreover, it clearly emerges from Figs. 7 and 8 that chabazite composition displays more evident deviations from fresh glass compositions with respect to phillipsite, especially in terms of calcium content.

The concentration, in the matrix, of a Ca-rich zeolite, like chabazite, clearly indicates that the matrix itself is character- 


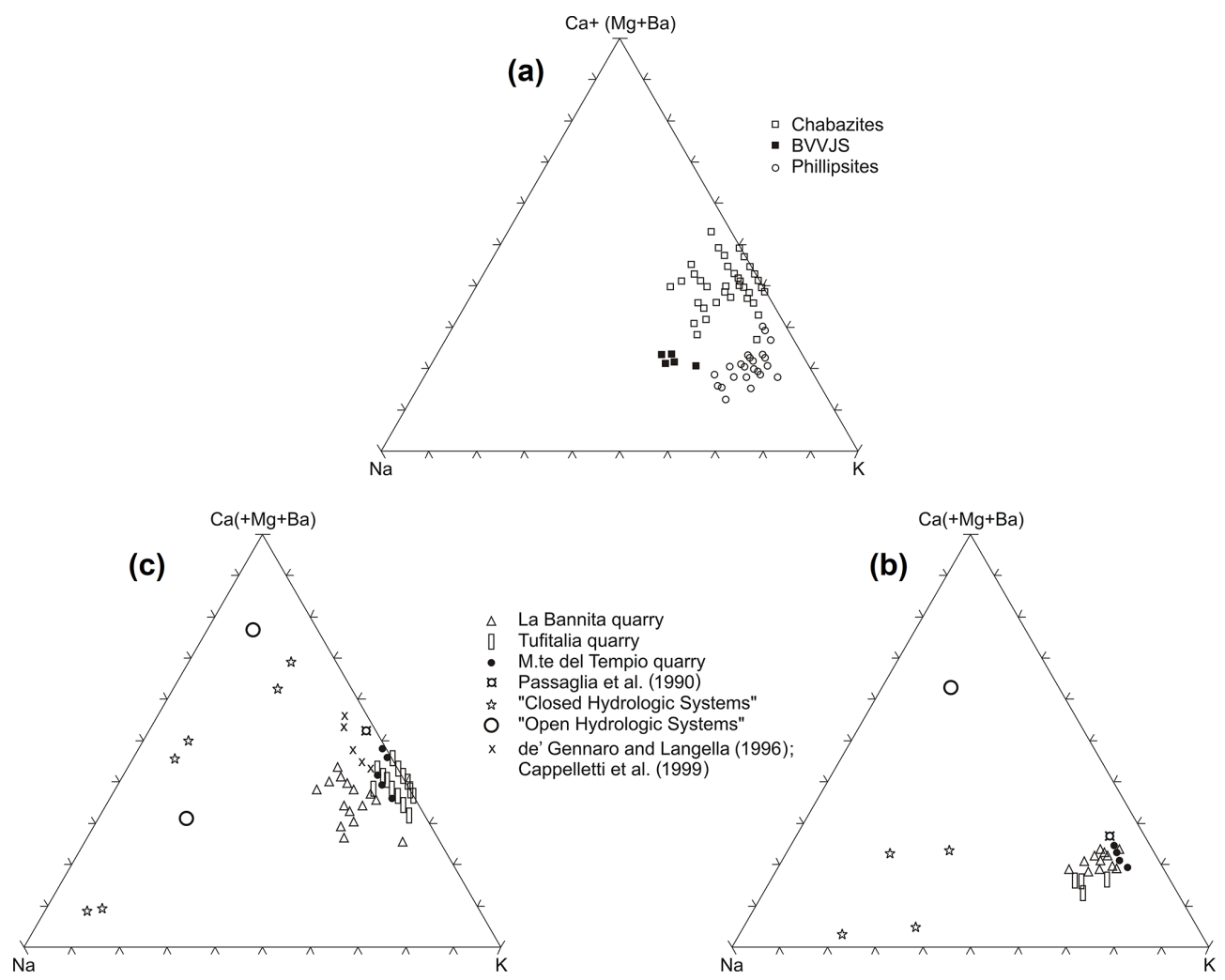

Figure 7. (a) Molar exchangeable cation content for TRS chabazites (empty square), TRS phillipsites (empty circles), and TRS fresh glasses (full squares). Values were calculated on the base of half of Barth's anhydrous standard cell content (Barth, 1952) for both zeolites and glasses. Mole plot of exchangeable cation content in TRS phillipsites (b) and chabazites (c). Zeolites from open and closed hydrologic systems are from Sheppard and Gude (1970, 1973), Hay (1964), and Iijima and Harada (1969).
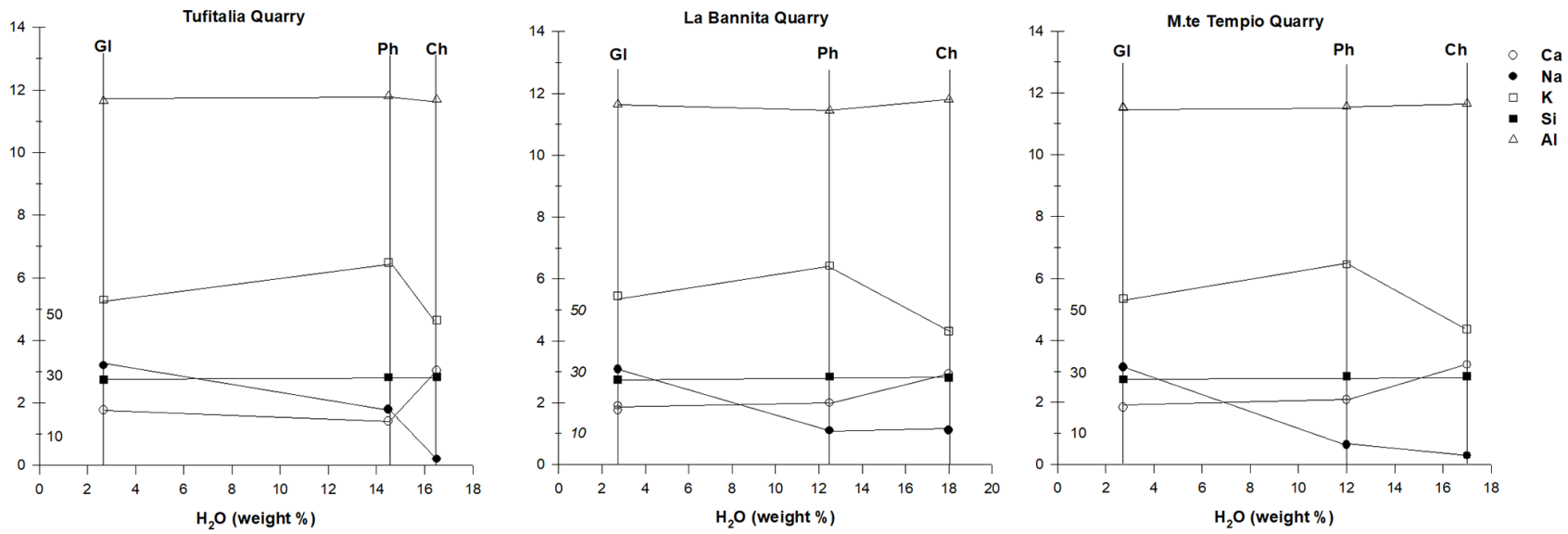

Figure 8. $\mathrm{Si}, \mathrm{Al}, \mathrm{Na}, \mathrm{K}$, and Ca variations during the zeolitization process in samples from Tufitalia quarry, La Bannita Quarry, and Mt Tempio Quarry. Water weight percentage is reported as an abscissa and half of Barth's anhydrous standard cell content as ordinates (Barth, 1952). For Si a compressed scale is used. GL: glass; $\mathrm{CH}$ : chabazite; $\mathrm{PH}$ : phillipsite.

ized by a higher $\mathrm{Ca}$ availability with respect to scoriae; one could hypothesize that contribution to high Ca content in the matrix is due to circulation of bicarbonate waters during the hydrothermal stage and also explains how this circulation is favoured in the more permeable matrix rather than in scoria fragments. Circulation of fluids rich in calcium bicarbonate is testified over more or less the whole TRS deposit, locally producing travertine deposits like those of the Civita Castellana Ponzano quarry (Giampaolo et al., 2008; de Gennaro et al., 1999). 
Table 4. Chemical analyses of chabazites. Chemical formula is calculated on the base of $24 \mathrm{O} . \mathrm{H}_{2} \mathrm{O}$ reported on a TG basis. MTQ: Monte Tempio quarry, Sutri; TIQ: Tufitalia quarry, Civita Castellana; BAN: La Bannita quarry, Castel S. Elia. No.: number of analyses. $\mathrm{E} \%=\{(\mathrm{Al}+\mathrm{Fe})-[\mathrm{Na}+\mathrm{K}+2(\mathrm{Ca}+\mathrm{Mg})]\} /[\mathrm{Na}+\mathrm{K}+2(\mathrm{Ca}+\mathrm{Mg})]$ (Passaglia et al., 1990). CEC: theoretical cation exchange capacity.

\begin{tabular}{lrrr}
\hline & MTQ & TIQ & BANQ \\
\hline $\mathrm{SiO}_{2}$ & 52.39 & 52.41 & 51.24 \\
$\mathrm{TiO}_{2}$ & 0.04 & 0.23 & 0.11 \\
$\mathrm{Al}_{2} \mathrm{O}_{3}$ & 18.30 & 18.40 & 18.20 \\
$\mathrm{Fe}_{2} \mathrm{O}_{3}$ & 0.07 & 0.13 & 0.12 \\
$\mathrm{MnO}$ & 0.03 & 0.02 & 0.02 \\
$\mathrm{MgO}$ & 0.08 & 0.20 & 0.03 \\
$\mathrm{CaO}$ & 5.42 & 5.25 & 4.99 \\
$\mathrm{BaO}$ & 0.06 & 0.04 & 0.05 \\
$\mathrm{Na} 2 \mathrm{O}$ & 0.27 & 0.20 & 1.04 \\
$\mathrm{~K} 2 \mathrm{O}$ & 6.34 & 6.62 & 6.20 \\
$\mathrm{H} 2 \mathrm{O}$ & 17.00 & 16.50 & 18.00 \\
\hline $\mathrm{Si}$ & 8.522 & 8.478 & 8.462 \\
$\mathrm{Ti}$ & - & 0.028 & 0.014 \\
$\mathrm{Al}$ & 3.496 & 3.508 & 3.544 \\
$\mathrm{Fe} 3+$ & 0.009 & 0.007 & 0.014 \\
$\mathrm{Mg}$ & 0.020 & 0.050 & 0.001 \\
$\mathrm{Ca}$ & 0.963 & 0.911 & 0.883 \\
$\mathrm{Na}$ & 0.086 & 0.069 & 0.334 \\
$\mathrm{~K}$ & 1.310 & 1.394 & 1.296 \\
$\mathrm{H} 2 \mathrm{O}$ & 9.190 & 8.905 & 9.910 \\
\hline $\mathrm{Si} / \mathrm{Al}$ & 2.43 & 2.42 & 2.39 \\
$\mathrm{Na} / \mathrm{K}$ & 0.07 & 0.05 & 0.26 \\
$\mathrm{E} \%$ & 4.94 & 4.57 & 3.25 \\
\hline $\mathrm{CEC}$ & 3.41 & 3.45 & 3.44 \\
\hline $\mathrm{No}$. & 5 & 19 & 21 \\
\hline & & & \\
\hline
\end{tabular}

As far as zeolitic formation is concerned, the more accredited model proposed for the tuffaceous rocks of the Lazio is the one proposed by Lenzi and Passaglia (1974) later called the "geoautoclave" model (Aleksiev and Djourova, 1975). The authors indicate that the TRS is limited above and below by non-zeolitized deposits and indicates high temperature, strictly related to the ignimbritic nature of TRS, as the main factor playing a fundamental role in the zeolitization process. Zeolitization took place in TRS as in a natural autoclave, for the presence of fluids heated by the thermal energy due to the ash tuff and retained in the deposit for some time.

Environment was characterized by high temperatures, probably between 120 and $230{ }^{\circ} \mathrm{C}$, suitable for zeolitization by interaction of fresh and highly reactive trachy-phonolitic glass with still hot circulating fluids. Fluids cause hydrolysis and dissolution of glassy fraction, determining a real-timechanging environment evidenced by a continuous chabazite crystallization (between 120 and $230^{\circ} \mathrm{C}$ ) with $\mathrm{Ca}$ depleting from fluids and consequent, relative $\mathrm{Na}$ enrichment that
Table 5. Chemical analyses of phillipsites. Chemical formula is calculated on the basis of $32 \mathrm{O}$. bdl: below detection limit. $\mathrm{H}_{2} \mathrm{O}$ reported on TG basis. MTQ: Monte Tempio quarry, Sutri; TIQ: Tufitalia quarry, Civita Castellana; BAN: La Bannita quarry, Castel S. Elia. No.: number of analyses. E\% = $\{(\mathrm{Al}+\mathrm{Fe})-[\mathrm{Na}+\mathrm{K}+2(\mathrm{Ca}+\mathrm{Mg})]\} /[\mathrm{Na}+\mathrm{K}+2(\mathrm{Ca}+\mathrm{Mg})]$ (Passaglia et al., 1990). CEC: theoretical cation exchange capacity.

\begin{tabular}{|c|c|c|c|}
\hline & MTQ & TIQ & BANQ \\
\hline $\mathrm{SiO}_{2}$ & 54.97 & 52.46 & 54.39 \\
\hline $\mathrm{TiO}_{2}$ & 0.01 & 0.11 & 0.10 \\
\hline $\mathrm{Al}_{2} \mathrm{O}_{3}$ & 18.90 & 18.62 & 18.56 \\
\hline $\mathrm{Fe}_{2} \mathrm{O}_{3}$ & 0.04 & 0.15 & 0.08 \\
\hline $\mathrm{MnO}$ & bdl & 0.04 & 0.03 \\
\hline $\mathrm{MgO}$ & bdl & 0.10 & 0.01 \\
\hline $\mathrm{CaO}$ & 3.74 & 2.51 & 3.55 \\
\hline $\mathrm{BaO}$ & 0.02 & 0.32 & 0.10 \\
\hline $\mathrm{Na}_{2} \mathrm{O}$ & 0.62 & 1.72 & 1.08 \\
\hline $\mathrm{K}_{2} \mathrm{O}$ & 9.70 & 9.45 & 9.60 \\
\hline $\mathrm{H}_{2} \mathrm{O}$ & 12.00 & 14.50 & 12.50 \\
\hline $\mathrm{Si}$ & 11.402 & 11.281 & 11.384 \\
\hline $\mathrm{Ti}$ & - & 0.021 & 0.014 \\
\hline $\mathrm{Al}$ & 4.622 & 4.719 & 4.577 \\
\hline $\mathrm{Fe}^{3+}$ & 0.007 & 0.024 & 0.013 \\
\hline $\mathrm{Mn}$ & - & 0.006 & - \\
\hline $\mathrm{Mg}$ & - & 0.032 & - \\
\hline $\mathrm{Ca}$ & 0.830 & 0.567 & 0.797 \\
\hline $\mathrm{Ba}$ & - & 0.027 & 0.008 \\
\hline $\mathrm{Na}$ & 0.251 & 0.717 & 0.439 \\
\hline K & 2.583 & 2.591 & 2.572 \\
\hline $\mathrm{H}_{2} \mathrm{O}$ & 8.312 & 10.401 & 8.721 \\
\hline $\mathrm{Si} / \mathrm{Al}$ & 2.47 & 2.39 & 2.49 \\
\hline $\mathrm{Na} / \mathrm{K}$ & 0.10 & 0.28 & 0.17 \\
\hline $\mathrm{E} \%$ & 3.10 & 2.68 & -1.01 \\
\hline CEC & 3.60 & 3.55 & 3.67 \\
\hline No. & 6 & 5 & 27 \\
\hline
\end{tabular}

favours phillipsite crystallization (between 150 and $230^{\circ} \mathrm{C}$ ). This real-time fluid chemical composition change determines the formation of two different zones: (1) a chabazite-rich zone and (2) a philipsite prevailing one. This distribution of the zeolite stability fields as a function of temperature is confirmed by the data of de Gennaro and Colella (1987), who treated trachytic and phonolitic glasses with deionized water at temperatures ranging from 100 to $270{ }^{\circ} \mathrm{C}$; the authors found that zeolitization began with the formation of phillipsite at temperatures between 100 and $250{ }^{\circ} \mathrm{C}$; the presence of chabazite, on the contrary, is revealed for longer times and at temperatures ranging from 150 to $270^{\circ} \mathrm{C}$.

This model can be validated by the phase diagram in Fig. 9, showing the coexistence of the previous three zeolites for thermodynamic conditions quite consistent with the 


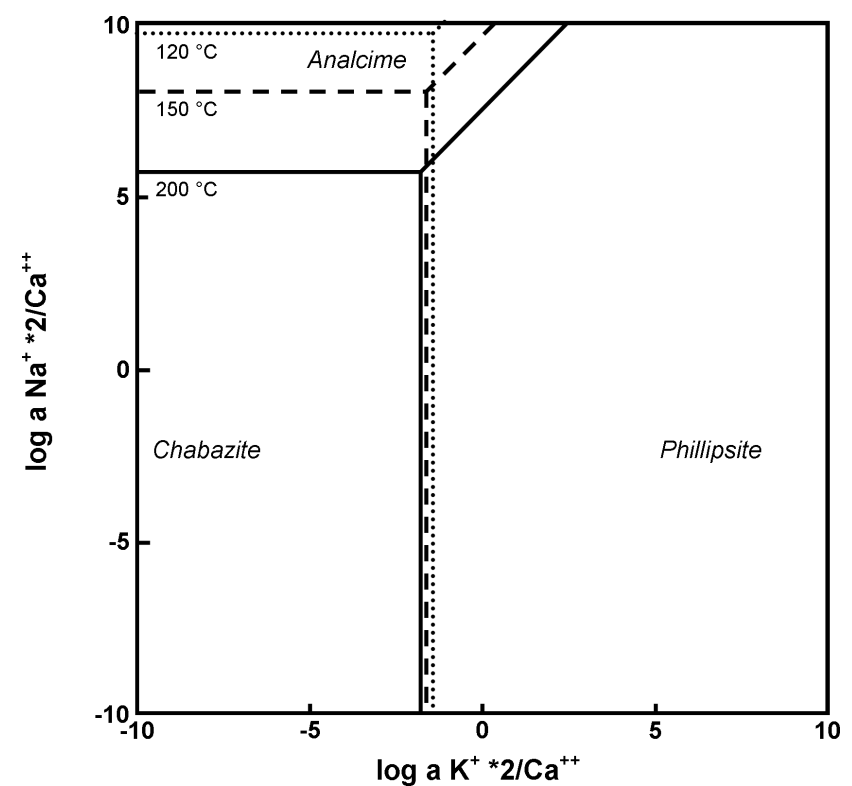

Figure 9. $\log$ a $\mathrm{K}^{+} \cdot 2 / \mathrm{Ca}^{++}$vs. $\log$ a $\mathrm{Na}^{+} \cdot 2 / \mathrm{Ca}^{++}$diagrams for zeolites of TRS at 120,150 , and $200^{\circ}$. $\log$ a $\mathrm{SiO}_{2}=-3.7 ; \log$ a $\mathrm{H}_{2} \mathrm{O}=1$.

considered system (temperature, cation activity, silica activity, and phase chemistry).

Passaglia et al. (1990) illustrate that the analysis of the $\mathrm{Si} / \mathrm{Al}$ ratio between fresh glasses and zeolites helps to define the genetic mechanism related to zeolitization processes. According to the authors, in fact, zeolites form by interaction of volcanic glass with waters that were originally (a) neutral ( $\mathrm{pH}$ around 7) in open hydrological systems and geoautoclaves, (b) moderately alkaline ( $\mathrm{pH} \sim 8$ ) in marine environments, and (c) strongly alkaline $(\mathrm{pH}>10)$ in closed hydrologic systems. So, as $\mathrm{Al}$ is more stable than $\mathrm{Si}$ with increasing $\mathrm{pH}$, zeolites formed in environments associated with neutral water circulation might display $\mathrm{Si} / \mathrm{Al}$ ratios similar to those relative to parental glasses in open hydrological systems and geoautoclaves; on the other hand, zeolites whose genesis is related to closed hydrologic systems and circulation of strongly alkaline aqueous solutions might show low $\mathrm{Si} / \mathrm{Al}$ ratios.

We found for TRS zeolites $\mathrm{Si} / \mathrm{Al}$ ratios similar to those of the parental glasses and ranging between 2.3 and 2.6 (Fig. 10), so we can confirm for Vico volcano zeolites a genesis related to a geoautoclave system.

In order to define the degree of the zeolitization process acting on TRS, the crystallization of the parental melts was followed in the phonolitic pentahedron sensu Baldridge et al. (1981) (Fig. 4). If the compositions of TRS plagioclase crystals are projected down to the $\mathrm{Ab}-\mathrm{Or}$ joint to point $\mathrm{A}$, then one can identify the triangle which has its vertexes A, B (TRS sanidine crystals compositions), and C (leucite crystals compositions). As is visible, this triangle encloses both TRS

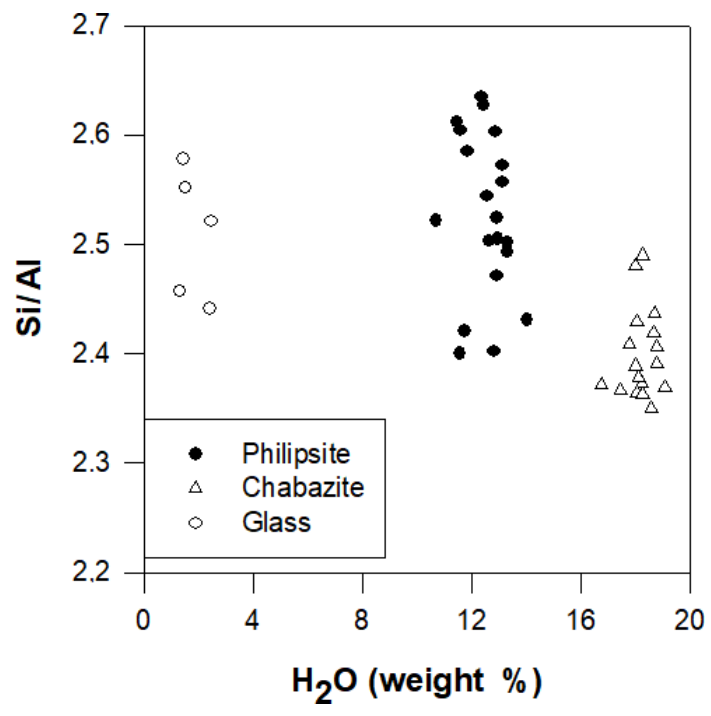

Figure 10. Si/Al ratio (calculated on the basis of half of Barth's anhydrous standard cell content) in zeolites and glasses of TRS versus water content (wt \%).

zeolitized rocks and fresh glasses, so demonstrating that the alteration processes acting on TRS are not so deeply developed to completely modify the parental rock chemical character. This approach, together with the similarity in the $\mathrm{Si} / \mathrm{Al}$ ratio between fresh glass and zeolites, led us to indicate that zeolitization processes operated on TRS rock without inducing considerable variations in the original rock chemistry.

\section{Conclusions}

Zeolites represent the result of the major secondary mineralization process acting on TRS deposits. Chabazite concentrated in the matrix and phillipsite and concentrated inside scoriae are the main observed phases. Secondary processes, acting on scoriae, always progress from the rim to the core as a function of temperature and circulation of gases and water inside the rock. In scoriae, the observed sequence can be summarized as follows: chabazite, phillipsite, analcime, and finally fresh glass.

The similarity in the $\mathrm{Si} / \mathrm{Al}$ ratio between fresh glass and zeolites helped to define a model for the TRS zeolitization referring to a geoautoclave system (Passaglia et al., 1990). The study of TRS paragenesis by the phonolitic pentahedron led us to define at which grade the zeolitization process acted on the volcanic rocks and the degree of the modification of the original bulk rock chemistry. This approach along with the abovementioned $\mathrm{Si} / \mathrm{Al}$ ratios analysis let us indicate that zeolitization processes operated on TRS rock without inducing considerable variations in original rock chemistry.

Differences in permeability between TRS scoriae and TRS matrix strongly influenced the type of zeolitization of the deposit. On the one hand, chabazites (more water-rich and more 
Ca selective) were more abundant in the ashy matrix due to the higher permeability with respect to pumices and $\mathrm{Ca}$ content (circulation of bicarbonatic water); on the other hand, phillipsites (lower $\mathrm{H}_{2} \mathrm{O}$ content) were more present in scoriae.

These low-temperature secondary minerogenetic processes can, certainly, generate zeolite deposits of economic interest. In the example shown in this study, peaks of $68 \mathrm{wt} \%$ are achieved by replacement of the amorphous fraction both in matrix and in scoriae, making the TRS a source of zeolites.

As is well known, zeolites can be considered suitable minerals for several technological applications (rather than their main use as cation exchangers) such as supplementary cementitious materials in the production of mixed cements (Snellings et al., 2012), with the main goal of reducing the amount of Portland cement used and accordingly reducing environmental impact of $\mathrm{CO}_{2}$ release.

Data availability. No data sets were used in this article.

Supplement. The supplement related to this article is available online at: https://doi.org/10.5194/ejm-33-315-2021-supplement.

Author contributions. DN, DG, PC, and SFG wrote the main manuscript text, and DN and SFG prepared figures and tables. All authors reviewed the manuscript.

Competing interests. The authors declare that they have no conflict of interest.

Acknowledgements. The technical and scientific staff of CCiT of the University of Barcelona helped us during laboratory work.

Review statement. This paper was edited by Rossella Arletti and reviewed by three anonymous referees.

\section{References}

Ackley, M. W., Rege, S. U., and Saxena, H.: Application of natural zeolites in the purification and separation of gases, Microp. and Mesop. Mat., 61, 25-42, https://doi.org/10.1016/S13871811(03)00353-6, 2003.

Aleksiev, B. and Djourova, E. G.: On the origin of zeolitic rocks, CR. Acaud. Bulg. Sci., 28, 517-520, 1975.

Andrew, R. M.: Global $\mathrm{CO}_{2}$ emissions from cement production, Earth Syst. Sci. Data, 10, 195-217, https://doi.org/10.5194/essd10-195-2018, 2018.

Aulinas, M., Gimeno, D., Cimarelli, C., De Rita, D., Giampaolo, C., Giordano, G., and Lomastro, S.: Estudio petrológico del volcanismo cuaternario de los Monti Cimini y el volcán de Vico, Lazio, Italia, Geotemas, 6, 147-150, https://doi.org/10.1344/105.000001642, 2011.

Baldridge, W. S., Carmichael, I. S. E., and Albee, A. L.: Crystallization paths of leucite bearing lavas: example from Italy, Contrib. Mineral. Petrol., 76, 321-335, https://doi.org/10.1007/BF00375459, 1981.

Barth, T. F. W.: Theoretical petrology, a textbook on the origin and evolution of rocks, John Wiley and Sons, New York, 416 pp., 1952.

Beccaluva, L., Di Girolamo, P., and Serri, G.: Petrogenesis and tectonic setting of the Roman Volcanic Province, Italy, Lithos, 26, 191-221, https://doi.org/10.1016/0024-4937(91)90029-K, 1991.

Cappelletti, P., Langella, A., de Gennaro, R., and Colella, A.: Mineralogical and technical features of zeolite deposits from northern Latium volcanic districts, Per. Mineral., 68, 127-144, 1999.

Cappelletti, P., Petrosino, P., de Gennaro, M., Colella, A., Graziano, S. F., D'Amore, M., Mercurio, M., Cerri, G., de Gennaro, R., Rapisardo, G., and Langella, A.: The "Tufo Giallo della Via Tiberina" (Sabatini Volcanic District, Central Italy): a complex system of lithification ina pyroclastic current deposit, Mineral. Petrol., 109, 85-101, https://doi.org/10.1007/s00710-014-0357z, 2015.

Ciccioli, P., Cattuto, C., Plescia, P., Valentini, V., and Negrotti, R.: Geochemical and engeneering geological properties of the volcanic tuffs used in the Etruscan tombs of Norchia (Northern Latium, Italy) and a study of the factors responsible for their rapid surface and structural decay, Archaeometry, 52, 229-251, https://doi.org/10.1111/j.1475-4754.2009.00464.x, 2010.

Colella, A., Di Benedetto, C., Calcaterra, D., Cappelletti, P., D’Amore, M., Di Martire, D., Graziano, S. F., Papa, L., and Langella, A.: The Neapolitan Yellow Tuff: An outstanding example of heterogeneity, Constr. Build. Mater., 136, 361-373, https://doi.org/10.1016/j.conbuildmat.2017.01.053, 2017.

Conticelli, S. and Peccerillo, A.: Petrology and geochemistry of potassic and ultrapotassic volcanism in central Italy: petrogenesis and inferences on the evolution of the mantle sources, Lithos, 28, 221-240, https://doi.org/10.1016/0024-4937(92)90008-M, 1992.

de Gennaro, B., Aprea, P., Colella, C., and Buondonno, A.: Comparative ion-exchange characterization of zeolitic and clayey materials for pedotechnical applications-Part 2: Interaction with nutrient cations, J. Porous Mat., 16, 667-673, https://doi.org/10.1007/s10934-008-9247-2, 2009.

de Gennaro, M. and Colella, C.: The critical role of temperature in the natural zeolitization of volcanic glass, N. Jb. Miner. Mh., 8, 355-362, 1991.

de Gennaro, M. and Langella, A.: Italian zeolitized rocks of technological interest, Mineral. Deposita, 31, 452-472, https://doi.org/10.1007/BF00196127, 1996.

de Gennaro, M., Franco, E., Rossi, M., Langella, A., and Ronca, A.: Epigenetic minerals in the volcaniclastic deposits from centralsouthern Italy: a contribution to zeolite genesis, in: The volcaniclastic rocks of Campania (southern Italy): Special Issue, edited by: Di Girolamo, P., Rendiconti Lincei-Scienze Fisiche Naturali, Naples, 107-131, 1987.

de Gennaro, M., Langella, A., Cappelletti, P., and Colella, C.: Hydrothermal conversion of trachytic glass to zeolite. 3. Monocationic model glasses, Clay Clay Miner., 47.3, 348-357, 1999. 
de Gennaro, R., Graziano, S. F., Cappelletti, P., Colella, A., Dondi, M., Langella, A., and de' Gennaro, M.: Structural concretes with waste-based lightweight aggregates: from landfill to engineered materials, Environ. Sci. Technol., 43, 7123-7129, 2009.

Esposito, L., Esposito, A. W., Pasculli, A., and Sciarra, N.: Particular features of the physical and mechanical characteristics of certain Phlegraean pyroclastic soils, Catena, 104, 186-194, https://doi.org/10.1016/j.catena.2012.11.009, 2013.

Gatta, G. D., Cappelletti, P., Rotiroti, N., Slebodnick, C., and Rinaldi, R.: New insights into the crystal structure and crystal chemistry of the zeolite phillipsite, Am. Mineral., 94, 190-199, https://doi.org/10.2138/am.2009.3032, 2009.

Giampaolo, C. and Lombardi, G.: Thermal behaviour of analcimes from two different genetic environments, Europ. J. Mineral., 6, 285-289, 1994.

Giampaolo, C., Mengarelli, L., Torracca, E., and Spencer, C.: Zeolite characterization of "Vico red tuff with black scoria" ignimbrite flow: The extractive district of Civita Castellana (Viterbo, Italy), Il Nuovo Cimento, 123B, 1459-1476, https://doi.org/10.1393/ncb/i2008-10722-4, 2008.

Gittings, J.: The feldspathoidal alkaline rocks, in: The evolution of the Igneous rocks: 50th Anniversari Perspectives, edited by: Yoder, H. S., Princeton Univ. Press, ISBN 9780691082240, 351390, 1979.

Gottardi, G. and Galli, E.: Natural zeolites. Springer-Verlag Berlin Heidelberg, New York, Tokyo, 409 pp., 1985.

Gualtieri, A. F.: Accuracy of XRPD QPA using the combined Rietveld-RIR method, J. Appl. Crystallogr., 33, 267-278, 2000.

Gualtieri, A. F. and Passaglia, E.: Rietveld structure refinement of NH4-exchanged natural chabazite, E. J. Min., 18, 351-359, 2006.

Hay, R. L.: Phillipsite of saline lakes and soils, Am. Mineral., 49, 1366-1387, 1964.

Iijima, A. and Harada, K.: Authigenic zeolites in zeolitic palagonite tuffs on Oahu, Hawaii. Am. Mineral., 54, 182-197, 1969.

Langella, A., Bish, D. L., Cappelletti, P., Cerri, G., Colella, A., de Gennaro, R., Graziano, S. F., Perrotta, A., Scarpati, C., and de Gennaro, M.: New insights into the mineralogical facies distribution of Campanian Ignimbrite, a relevant Italian industrial material, Appl. Clay Sci., 72, 55-73, https://doi.org/10.1016/j.clay.2013.01.008, 2013.

Larson, A. C. and Von Dreele, R. B.: Document LAUR 86-748, Los Alamos National Laboratory, 1997.

Le Maître, R. W.: A classification of Igneous rocks and Glossary of Terms, Blackwell Scientific Publications, ISBN 9780632025930, 193 pp., 1989.

Lenzi, G. and Passaglia, E.: Fenomeni di zeolitizzazione nelle formazioni vulcaniche della regione Sabatina, Boll. Soc. Geol. It., 93, 623-645, 1974.

Mertens, G., Snellings, R., Van Balen, K., Bicer-Simsir, B., Verlooy, P., and Elsen, J.: Pozzolanic reactions of common natural zeolites with lime and parameters affecting their reactivity, Cement Concrete Res., 39, 233-240, https://doi.org/10.1016/j.cemconres.2008.11.008, 2009.

Novembre, D.: Zeoliti naturali e sintetiche, metodologie di sintesi da reagenti chimici e da materiali naturali, $\mathrm{PhD}$ Thesis, Chieti University, Italy, 196 pp., 2003.

Novembre, D. and Gimeno, D.: Syntheses and characterization of zeolites K-F and W type using a diatomite precursor, Min. Mag.,
78, 1209-1225, https://doi.org/10.1180/minmag.2014.078.5.08, 2014.

Novembre, D. and Gimeno, D.: The solid state conversion of kaolin to KAlSiO4 minerals: the effects of time and temperature, Clay Clay Miner., 65, 355-366, https://doi.org/10.1346/CCMN.2017.064077, 2017.

Novembre, D., Di Sabatino, B., Gimeno, D., García Vallés, M., and Martínez Manent, S.: Synthesis of Na-X zeolites from tripolaceous deposits (Crotone, Italy) and volcanic zeolitized rocks (Vico Volcano, Italy), Microp. Mesop. Mat., 75, 1-11, https://doi.org/10.1016/j.micromeso.2004.06.022, 2004.

Novembre, D., Gimeno, D., and Poe, B.: Diatomite as natural precursor for the synthesis of $\mathrm{KAlSiO}_{4}-\mathrm{O} 1$, Eur. J. Mineral., 30 , 1127-1132, https://doi.org/10.1127/ejm/2018/0030-2782, 2018.

Novembre, D., Gimeno, D., and Poe, B.: Synthesis and characterization of Leucite using a Diatomite precursor, Sci. Rep., 9, 10051-10061, https://doi.org/10.1038/s41598-019-46569-y, 2019.

Özen, S., Göncüoğlu, M. C., Liguori, B., de Gennaro, B., Cappelletti, P., Gatta, G. D., Iucolano, F., and Colella, C.: A comprehensive evaluation of sedimentary zeolites from Turkey as pozzolanic addition of cement- and lime-based binders, Constr. Build. Mater., 105, 46-61, https://doi.org/10.1016/j.conbuildmat.2015.12.055, 2016.

Passaglia, E., Vezzalini, G., and Carnevali, R.: Diagenetic chabazites and phillipsites in Italy: crystal chemistry and genesis, Eur. J. Mineral., 2, 827-839, 1990.

Peccerillo, A., Conticelli, S., and Manetti P.: Petrological characteristics and the genesis of the recent magmatism of Southern Tuscany and Northern Latium, Per. Mineral., 56, 157-172, 1987.

Perini, G., Conticelli, S., and Francalanci, L.: Inferences on the volcanic history of the Vico volcano, Roman Magmatic Province, Central Italy: stratigraphic, petrographic and geochemical data, Miner. Petrogr. Acta, 40, 67-93, 1997.

Ruggieri, F., Marín, V., Gimeno, D., Fernandez-Turiel, J. L., GarciaValles, M., and Gutierrez, L.: Application of zeolitic volcanic rocks for arsenic removal from water, Eng. Geol., 10, 245-250, https://doi.org/10.1016/j.enggeo.2008.06.006, 2008.

Serri, G., Innocenti, F., and Manetti, P.: Geochemical and petrological evidence of the subduction of delaminated Adriatic continental lithosphere in the genesis of the Neogene-Quaternary magmatism of central Italy, Tectonophysics, 223, 117-147, 1993.

Sheppard, R. A. and Gude, A. J.: Calcic siliceous chabazite from the John Day Formation, Grant County, Oregon, US Geological Survey Prof Papers, 700-D, 176-180, 1970.

Sheppard, R. A. and Gude, A. J.: Zeolites and associated authigenic silicate minerals in tuffaceous rocks of the Big Sandy Formation, Mohave County, Arizona, US. Geol. Surv. Prof. Pap., 830, 1-36, 1973.

Snellings, R., Mertens, G., Gasharova, B., Garbev, K., and Elsen, J.: The pozzolanic reaction between clinoptilolite and portlandite: a time and spatially resolved IR study, Eur. J. Mineral., 22, 767777, https://doi.org/10.1127/0935-1221/2010/0022-2019, 2010a

Snellings, R., Mertens, G., and Elsen, J.: Calorimetric evolution of the early pozzolanic reaction of natural zeolites, J. Therm. Anal. Calorim., 101, 97-105, https://doi.org/10.1007/s10973009-0449-x, 2010b. 
Snellings, R., Mertens, G., and Elsen, J.: Supplementary cementitious materials, Rev. Mineral. Geochem., 74, 211-278, https://doi.org/10.2138/rmg.2012.74.6, 2012.

Stumm, W. and Morgan, J. J.: Aquatic Chemistry. An Introduction Emphasizing Chemical Equilibria in Natural Waters, 2nd Edn., John Wiley and Sons, New York, ISBN 978-0471091738, 1981.

Toby, B. H.: EXPGUI, a Graphical User Interface for GSAS, J. Appl. Crystallogr., 34, 210-213, https://doi.org/10.1107/S0021889801002242, 2001.

Wang, S. and Peng, Y.: Natural Zeolites as Effective Adsorbents in Water and Wastewater Treatment, Chem. Eng. J., 156, 11-24, https://doi.org/10.1016/j.cej.2009.10.029, 2010.
Whitney, D. L. and Evans, B. W.: Abbreviations for names of rock-forming minerals, Am. Mineral., 95, 185-187, https://doi.org/10.2138/am.2010.3371, 2010.

Wolery, T. J., Sherwood, D. J., Jackson, K. J., Delany, J. M., and Puigdomenech, I.: EQ3/6 Status and Applications, UCRL-91884 (DE85 006902), Lawrence Livermore Laboratory, Livermore, California, 1984. 